\title{
Could exotic mosquito-borne diseases emerge in Canada with climate change?
}

\author{
V Ng ${ }^{1 *}$, EE Rees ${ }^{1}$, LR Lindsay ${ }^{1}$, MA Drebott ${ }^{1}$, T Brownstone $^{1,2}$, T Sadeghieh $^{1,3}$, SU Khan $^{1,3}$
}

\begin{abstract}
Of the 3,500 species of mosquitoes worldwide, only a small portion carry and transmit the mosquito-borne diseases (MBDs) that cause approximately half a million deaths annually worldwide. The most common exotic MBDs, such as malaria and dengue, are not currently established in Canada, in part because of our relatively harsh climate; however, this situation could evolve with climate change. Mosquitoes native to Canada may become infected with new pathogens and move into new regions within Canada. In addition, new mosquito species may move into Canada from other countries, and these exotic species may bring exotic MBDs as well. With high levels of international travel, including to locations with exotic MBDs, there will be more travel-acquired cases of MBDs. With climate change, there is the potential for exotic mosquito populations to become established in Canada. There is already a small area of Canada where exotic Aedes mosquitoes have become established although, to date, there is no evidence that these carry any exotic (or already endemic) MBDs. The increased risks of spreading MBDs, or introducing exotic MBDs, will need a careful clinical and public health response. Clinicians will need to maintain a high level of awareness of current trends, to promote mosquito bite prevention strategies, and to know the laboratory tests needed for early detection and when to report laboratory results to public health. Public health efforts will need to focus on ongoing active surveillance, public and professional awareness and mosquito control. Canadians need to be aware of the risks of acquiring exotic MBDs while travelling abroad as well as the risk that they could serve as a potential route of introduction for exotic MBDs into Canada when they return home.
\end{abstract}

This work is licensed under a Creative Commons Attribution 4.0 International License.

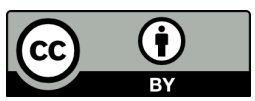

Affiliations

${ }^{1}$ National Microbiology Laboratory, Public Health Agency of Canada, Guelph, ON, St. Hyacinthe, QC and Winnipeg, MB

2 Dalla Lana School of Public Health, University of Toronto, Toronto, ON

${ }^{3}$ Department of Population Medicine, University of Guelph, Guelph, ON

*Correspondence: victoria.ng@ canada.ca

Suggested citation: Ng V, Rees EE, Lindsay LR, Drebot MA, Brownstone T, Sadeghieh T, Khan SU. Could exotic mosquito-borne diseases emerge in Canada with climate change? Can Commun Dis Rep 2019;45(4):98-107. https://doi.org/10.14745/ccdr.v45i04a04

Keywords: mosquito-borne disease, Canada, climate change, international travel, exotic vectors, Aedes albopictus, Culex mosquitoes, Anopheles species

\section{Introduction}

Mosquitoes cause approximately half a million deaths annually through the transmission of a range of mosquito-borne diseases (MBDs) (1). The majority of MBDs, including malaria, dengue, chikungunya virus (CHIKV) and Zika virus (ZIKV), are transmitted to humans by mosquitoes that are not currently established in Canada (2-4). Most of the important vectors are mosquitoes from the Aedes and Anopheles genera. These mosquitoes are exotic to Canada because our cooler climate and particularly our harsh winters, prevent these mosquitoes from becoming established here. In contrast, mosquitoes that are endemic to Canada, including Culex pipiens, Cx. restuans and Cx. tarsalis, which are the primary vectors for West Nile virus in Canada, can survive over winter by entering diapause and, in general, have lower developmental temperature thresholds than tropical/ subtropical species (5). Accordingly, MBDs transmitted by exotic mosquitoes are restricted to being acquired abroad, while MBDs transmitted by endemic mosquitoes are acquired both abroad and locally in Canada during the warmer months of the year (6-10).

It is well known that MBDs are sensitive to climate, and that climatic conditions set the limits on the geography and seasonality of transmission; this is reflected in the distinct and often predictable seasonal distribution of MBDs (11). A question that is often asked is: might climate change enable exotic MBDs to emerge and become established in Canada? The objectives of this paper are to identify the following: the exotic mosquitoes that carry pathogens causing human diseases; travel-acquired cases of exotic MBDs that have been reported in Canada; the climatic changes that could create local ecosystems in Canada that are conducive to the survival of exotic mosquitoes and the transmission of exotic MBDs; the potential routes of introduction of exotic MBDs into Canada as a result of climate change; and a summary of the clinical and public health implications. 


\section{Exotic mosquitoes that carry pathogens that cause human diseases}

There are approximately 3,500 known species of mosquitoes worldwide, but only a small number can carry and transmit pathogens that cause illness in humans. The most prolific carriers and transmitters of exotic diseases to humans are Aedes genus mosquitoes. These mosquitoes, in particular Ae. aegypti and Ae. albopictus, have the potential to transmit over 20 pathogens that are infectious to humans including dengue, CHIKV, ZIKV and yellow fever $(12,13)$. Aedes aegypti and Ae. albopictus are more widely distributed globally than any other mosquito species that are known to transmit diseases to humans $(2,3)$. Collectively, their impact is far-reaching: between 1952 and 2017, the overall numbers of countries/territories reporting autochthonous mosquito-borne transmission of dengue, CHIKV, ZIKV and yellow fever were estimated to be 111, 106, 85 and 43, respectively (14). The highly anthropophilic behaviour of Ae. aegypti and Ae. albopictus makes them two of the most medically-important mosquito species worldwide (15).

The Anopheles genus of mosquitoes also carry and transmit pathogens that cause diseases of importance to humans; these include malaria and lymphatic filariasis (Table 1). Up to 41 Anopheles species have been identified as vectors for malaria (4); three of these are co-carriers of parasites causing lymphatic

Table 1: Common vectors of exotic mosquito-borne diseases in humans and the main diseases they carry

\begin{tabular}{|c|c|c|c|c|}
\hline $\begin{array}{l}\text { Mosquito } \\
\text { genus }\end{array}$ & $\begin{array}{l}\text { Mosquito species or species } \\
\text { complex }\end{array}$ & Global distribution & Main disease/s carried & References \\
\hline \multirow{5}{*}{ Aedes } & Ae. aegypti & $\begin{array}{l}\text { North and South America, Middle } \\
\text { East, Africa, India/Western Asia and } \\
\text { Southeast Asia and the Pacific }\end{array}$ & $\mathrm{CHIKV}$, dengue, YF and ZIKV & $(2,3,14)$ \\
\hline & Ae. albopictus ${ }^{a}$ & $\begin{array}{l}\text { North and South America, Europe and } \\
\text { Middle East, Africa, India/Western Asia } \\
\text { and Southeast Asia and the Pacific }\end{array}$ & $\begin{array}{l}\text { CHIKV, dengue and ZIKV (to a lesser } \\
\text { degree than } A e \text {. aegypti) }\end{array}$ & $(2,3,14,20)$ \\
\hline & Ae. polynesiensis & South Pacific Islands & LF (W. bancrofti) and dengue & $(12)$ \\
\hline & Ae. scapularis & North and South America & LF (W. bancrofti) & $(12)$ \\
\hline & Ae. pseudoscutellaris & South Pacific Islands & LF (W. bancrofti) and dengue & $(12,21,22)$ \\
\hline \multirow{5}{*}{ Anopheles } & $\begin{array}{l}\text { An. albimanus, An. albitarsis, } \\
\text { An. aquasalis, An. darlingi, } \\
\text { An. freebornib, An. marajoara, } \\
\text { An. nuneztovari, An. } \\
\text { pseudopunctipennis, An. } \\
\text { quadrimaculatus }{ }^{b}\end{array}$ & North and South America & Malaria & $(4,19)$ \\
\hline & $\begin{array}{l}\text { An. atroparvus, An. labranchiae, } \\
\text { An. messeae, An. sacharovi, An. } \\
\text { sergentii, An. superpictus }\end{array}$ & Europe and Middle East & Malaria & (4) \\
\hline & $\begin{array}{l}\text { An. arabiensis, An. funestus }{ }^{c}, \text { An. } \\
\text { gambiaec, An. melas, An. merus, } \\
\text { An. moucheti, An. nili }\end{array}$ & Africa & $\begin{array}{l}\text { Malaria } \\
\text { Malaria and LF (W. bancrofti })^{c}\end{array}$ & $(4,12,23)$ \\
\hline & $\begin{array}{l}\text { An. culicifacies, An. stephensi, An. } \\
\text { fluviatilis }\end{array}$ & India/Western Asia & Malaria & (4) \\
\hline & $\begin{array}{l}\text { An. aconitus, An. annularis, An. } \\
\text { balabacensis, An. barbirostris }{ }^{d}, \\
\text { An. culicifacies, An. dirus, An. } \\
\text { farauti, An. flavirostris, An. } \\
\text { fluviatilis, An. koliensis, An. } \\
\text { lesteri, An. leucosphyrus/latens, } \\
\text { An. maculatus, An. minimus, An. } \\
\text { punctulatus, An. sinensis, An. } \\
\text { stephensi, An. subpictus, An. } \\
\text { sundaicus }\end{array}$ & Southeast Asia and the Pacific & $\begin{array}{l}\text { Malaria } \\
\text { Malaria and LF (B. timori })^{d}\end{array}$ & $(4,12)$ \\
\hline \multirow{2}{*}{ Culex } & Cx. tritaeniorhychus & $\begin{array}{l}\text { Southeast Asia and the Pacific, Africa, } \\
\text { Middle East }\end{array}$ & $\begin{array}{l}\text { JE, Rift Valley fever, Murray Valley } \\
\text { encephalitis virus }\end{array}$ & $(24,25)$ \\
\hline & Cx. quinquefasciatus & $\begin{array}{l}\text { North, Central and South America, } \\
\text { Southeast Asia }\end{array}$ & LF (W. bancrofti) & $(12,23)$ \\
\hline Mansonia & Various species & Asia and the Pacific & LF (B. malayi) & $(12,23)$ \\
\hline
\end{tabular}

Abbreviations: Ae., Aedes; An., Anopheles; B., Brugia; CHIKV, chikungunya virus; Cx., Culex; JE, Japanese encephalitis; LF, lymphatic filariasis; W., Wuchereria; YF, yellow fever; ZIKV, Zika virus a Species that have recently established in Canada (20)

b Species that are established in Canada (19)

'Species (An. funestus and An. gambiae) that transmit both malaria and LF (W. bancrofti)

${ }^{d}$ Species (An. barbirostris) that transmit both malaria and LF (B. timori) 
filariasis (12). Each vector has a distinct geographic dominance with multi-species coexistence, and distribution is generally worldwide across the tropics and subtropics $(4,16)$. Globally, they are responsible for autochthonous malaria transmission in 87 countries, with a concentration of cases in Africa and India (17). Concomitantly, over 70 countries in sub-Saharan Africa, Southeast Asia and the Pacific Islands report local lymphatic filariasis transmission (18). Of the most common mosquitoes carrying diseases exotic to Canada, only two are established here (Table 1); An. freeborni and An. quadrimaculatus, the principal vectors for malaria. Additionally, Ae. albopictus, a principal vector for dengue, CHIKV, ZIKV and yellow fever, appears to have emerged and established in a very limited part of Southwestern Ontario in $2017(19,20)$. Other mosquitoes that carry diseases exotic to Canada include Culex and Mansonia species. Diseases that are carried by these mosquitoes include lymphatic filariasis, Japanese encephalitis, Rift Valley fever and Murray Valley encephalitis (12).

\section{Travel-acquired exotic mosquito-borne diseases}

International travel is very common; approximately 4.75 million Canadian residents returned from abroad each month between 2014 and 2018; 3.77 million (82\%) from the United States (US) and 985,000 (21\%) from elsewhere (26). The most common destinations outside of the USA are Mexico, Western Europe and the Caribbean (including Cuba, Dominican Republic and The Bahamas) (27). It is, therefore, not surprising that Canadian residents often return with sporadic travel-acquired exotic MBDs; the most common being malaria and dengue $(9,28,29)$. Each year, approximately 500 cases of travel-acquired malaria are reported in returned travellers (30). While dengue is not a notifiable disease in Canada, the National Microbiology Laboratory identified over 250 cases between 2012 and 2017, and a significant number of additional cases were documented by provincial public health laboratories in the same time period (unpublished data, Michael Drebot, National Microbiology Laboratory, Winnipeg, Canada). Dengue is currently considered one of the most critical MBDs worldwide and is of concern for Canadian residents given the 30 -fold increase in global incidence over the past 50 years $(31,32)$. The recent incursion of $\mathrm{CHIKV}$ and ZIKV into the western hemisphere and subsequent epidemic in the Caribbean and the Americas demonstrate the potential for exotic MBDs to spread extensively and rapidly across large vulnerable populations $(33,34)$. As a result of the presence of MBDs worldwide, including in countries frequented by Canadian travellers, hundreds of residents returned to Canada with travel-acquired CHIKV and ZIKV between 2013 and 2017 (7,8,10,35). Other common MBDs of concern for returned travellers include yellow fever, Japanese encephalitis and lymphatic filariasis. The recent outbreaks of yellow fever in Brazil and parts of Africa are a threat for Canadian residents travelling in those regions (36-38), although confirmed cases in returned travellers remain low (14 cases between 2008 and 2016) (30) possibly due to the highly effective yellow fever vaccine recommended for Canadian travellers $(39,40)$. The number of travel-acquired Japanese encephalitis and lymphatic filariasis cases is unknown as these diseases are not notifiable in Canada, but it is expected to be considerable given their high annual incidence globally (1). Collectively, exotic MBDs result in thousands of travel-acquired infections annually in returned travellers.

\section{Climate changes may create ecosystems for exotic mosquitoes}

All parts of Canada are expected to experience climate change, but the impact will vary across regions, with the highest impact expected in the north (41). A global warming of approximately $2^{\circ} \mathrm{C}$ is expected to bring milder temperatures, increased precipitation and humidity and more frequent extreme heat and precipitation events. As a result, winters are expected to be milder and shorter, while summers will be warmer and longer. A global warming of approximately $4^{\circ} \mathrm{C}$ is very likely to cause even greater changes, with extreme heat events, daily-scale precipitation extremes and a further increase in annual precipitation across most parts of Canada, but particularly in the north (41). There are many ways in which these climate changes are expected to facilitate the emergence and transmission of exotic MBDs in Canada. Warmer temperature, higher humidity and increased precipitation will facilitate the lifecycle of exotic mosquitoes by supporting larval development and survival and extending adult lifespan, thus increasing overall population size (42-45). Climate change is also expected to influence disease transmission via several mechanisms:

- Reducing egg development time in recently-fed adult female mosquitoes, thus reducing the time between blood meals and increasing feeding frequency $(42,43,46)$

- Shortening the extrinsic incubation period, thereby allowing mosquitoes to become infectious faster $(42,43,45-48)$

- Increasing mosquito longevity, enabling infectious mosquitoes to bite more people (44)

As temperatures in Canada become milder and humidity and precipitation increase, larger parts of Canada will become climatically suitable for the establishment of some exotic mosquitoes that are currently limited to the tropics and subtropics $(3,49,50)$. Furthermore, as the winters become shorter and summers become longer, the duration of climatic suitability for disease transmission will increase, allowing autochthonous transmission of exotic MBDs for a limited period in some regions of Canada (49). For exotic MBDs that are zoonoses and require an animal reservoir that is currently present in Canada 
(e.g. Japanese encephalitis), climate change could have further impact on the reservoir such as maintaining and supporting the expansion of natural habitats and prolonging the availability of food sources, thus increasing population size $(51,52)$. Extreme weather events, such as droughts and heat events, can bring host reservoirs searching for water sources and mosquito breeding grounds together (53-55).

\section{Introduction of exotic mosquito-borne disease pathogens into Canada}

For exotic MBD emergence, a competent mosquito vector, an appropriate reservoir host (if any) and the exotic pathogen must be brought together in a suitable habitat. While climate change can create additional habitats for mosquitoes and reservoir hosts, the pathogen needs to be introduced into Canada either via infected mosquitoes, viraemic humans and/or viraemic reservoirs $(56,57)$. Pathogen introduction can occur either locally or globally.

Local introduction can occur during short-distance movement of mosquitoes/reservoirs/humans from a neighbouring endemic region into Canada. Exotic MBDs that may emerge through local introduction include Saint Louis encephalitis virus and La Crosse encephalitis virus because their vectors are already present in Canada and endemic in the US (58-60). If climate change influences or leads to increased seasonal abundance and expansion of specific mosquito vectors (e.g. Ae. triseriatus), there is a higher risk for the spread of these pathogens to additional geographic regions in the country. Locally-acquired cases of exotic MBDs will likely emerge, with a high possibility of these diseases becoming endemic over time.

Global introduction can arise from long-distance movement (international travel, migration or trade/transportation of goods) of mosquitoes/reservoirs/humans from a distant endemic region into Canada. There are two global introduction scenarios in which vectors are either present or absent in Canada (Table 2). When the vector is present, climate change will likely increase travel-acquired cases of exotic MBDs by amplifying the natural transmission cycle and the likelihood of contact between vectors/ reservoirs/humans in the country of origin, permit short-lived autochthonous transmission in Canada (as observed for CHIKV and ZIKV elsewhere) (61-66) with the possibility of becoming endemic over time (as demonstrated by West Nile virus) (6,67-69). Diseases that may emerge under this scenario include malaria and CHIKV, because established or recently-emerged vector populations of these diseases are already present in Canada $(19,20)$. When the vector is absent, and restrictions in the ecological niche of vectors may prevent establishment even with climate change, the impact of climate change will be limited to an increase in travel-acquired cases with no further local mosquito-borne transmission. While some types of global movement are linked to climate change [e.g. climate refugees
(70) and changes in travel patterns (71)], many are not; however, global movement is increasing (72) and Canadians are avid travellers (26), so even without the influence of climate change, global movement will continue to support emergence of exotic MBDs in Canada.

\section{Clinical and public health implications}

As climate change is anticipated to increase the risks for introduction of exotic MBDs into Canada and travel- and locally-acquired exotic MBDs in Canadian residents, vigilant clinical and public health response is essential. Clinicians should maintain a high level of awareness of current exotic MBD trends, promote mosquito bite prevention strategies by travellers, be aware of the laboratory tests needed for early detection and report notifiable diseases to public health. Public health professionals should focus on supporting ongoing active surveillance of exotic mosquitoes and pathogens, promoting public and professional awareness of exotic MBDs and mosquito control, including bite prevention. Canadian travellers need to be more aware of the risks that they could be acquiring exotic MBDs while travelling abroad as well as the risk that they could serve as a potential route of introduction for exotic MBDs into Canada. They can do this by seeking advice from local travel medicine clinics or by reviewing the travel health and safety sections of the government website (travel.gc.ca) prior to leaving the country.

\section{Discussion}

The most common travel-acquired exotic MBDs in Canada are malaria, dengue, CHIKV and ZIKV (7-10,28,29). Exotic mosquitoes that carry and transmit these diseases to humans are from the Anopheles and Aedes genera (12). Currently, most of these mosquitoes are not present in Canada, but An. freeborni and An. quadrimaculatus (principal vectors for malaria) are widespread. Small numbers of Ae. aegypti and Ae. albopictus (principal vectors for dengue, CHIKV, ZIKV and yellow fever) have been introduced into parts of Canada and populations of the latter have recently established in a very limited region in Canada $(19,20)$.

Climate change is expected to create and expand suitable habitats for exotic and endemic mosquitoes and their host reservoirs $(3,42,50-52,74,75)$ and allow for establishment of exotic MBDs. Physiological changes in mosquitoes would increase their survival and ability to transmit diseases to humans (42-48). In addition, lengthening the duration of climatic suitability for disease transmission $(49,76)$ could occur simultaneously both in Canada and in countries where exotic MBDs are already circulating. Climate change will also have an impact on the movement of vectors/reservoirs/humans and thus influence the introduction of exotic MBDs into Canada $(70,71)$. 
Table 2: Three routes of introduction of exotic mosquito-borne pathogens into Canada

\begin{tabular}{|c|c|c|c|}
\hline Consideration & Local movement & $\begin{array}{c}\text { Global movement, vector/s } \\
\text { present }\end{array}$ & Global movement, vector/s absent \\
\hline $\begin{array}{l}\text { Emergence arising from } \\
\text { local or global movement }\end{array}$ & $\begin{array}{l}\text { Short-distance movement at the } \\
\text { local scale }\end{array}$ & $\begin{array}{l}\text { Long-distance movement at the } \\
\text { global scale }\end{array}$ & $\begin{array}{l}\text { Long-distance movement at the global } \\
\text { scale }\end{array}$ \\
\hline $\begin{array}{l}\text { How geographic emergence } \\
\text { may occur in Canada }\end{array}$ & $\begin{array}{l}\text { Natural and regular movements } \\
\text { of vectors/reservoirs/humans } \\
\text { from a neighbouring endemic } \\
\text { region }\end{array}$ & $\begin{array}{l}\text { International travel, trade/ } \\
\text { transportation and migration of } \\
\text { vectors/reservoirs/humans from a } \\
\text { distant endemic region }\end{array}$ & $\begin{array}{l}\text { International travel, trade/transportation } \\
\text { and migration of vectors/reservoirs/ } \\
\text { humans from a distant endemic region }\end{array}$ \\
\hline Pathogen & $\begin{array}{l}\text { Present in a neighbouring } \\
\text { endemic region (i.e. bordering a } \\
\text { US state) but not in Canada }\end{array}$ & $\begin{array}{l}\text { Present in a distant endemic region } \\
\text { but not in Canada }\end{array}$ & $\begin{array}{l}\text { Present in a distant endemic region but } \\
\text { not in Canada }\end{array}$ \\
\hline Vector mosquitoes present & Yes & Yes & No \\
\hline \multirow{2}{*}{$\begin{array}{l}\text { Impact of climate change on } \\
\text { emergence }\end{array}$} & \multirow{2}{*}{$\begin{array}{l}\text { Amplify the natural transmission } \\
\text { cycle and increase the likelihood } \\
\text { of contact between vectors/ } \\
\text { reservoirs/humans in Canada }\end{array}$} & $\begin{array}{l}\text { Amplify the natural transmission } \\
\text { cycle and increase the likelihood of } \\
\text { contact between vectors/reservoirs/ } \\
\text { humans in Canada and in the country } \\
\text { of origin }\end{array}$ & $\begin{array}{l}\text { Amplify the natural transmission cycle } \\
\text { and increase the likelihood of contact } \\
\text { between vectors/reservoirs/humans in } \\
\text { Canada and in the country of origin }\end{array}$ \\
\hline & & $\begin{array}{l}\text { Pathogen must be imported into } \\
\text { Canada via infected mosquitoes or } \\
\text { viraemic humans/reservoirs (driven } \\
\text { primarily by global movement and } \\
\text { partially by climate change) }\end{array}$ & $\begin{array}{l}\text { Pathogen must be imported into Canada } \\
\text { via infected mosquitoes or viraemic } \\
\text { humans/reservoirs (driven primarily by } \\
\text { global movement and partially by climate } \\
\text { change) }\end{array}$ \\
\hline $\begin{array}{l}\text { Current disease presentation } \\
\text { in Canada }\end{array}$ & $\begin{array}{l}\text { Travel-acquired cases from the } \\
\text { US }\end{array}$ & $\begin{array}{l}\text { Travel-acquired cases from the US } \\
\text { and globally }\end{array}$ & $\begin{array}{l}\text { Travel-acquired cases from the US and } \\
\text { globally }\end{array}$ \\
\hline $\begin{array}{l}\text { Diseases that may emerge in } \\
\text { Canada with climate change }\end{array}$ & $\begin{array}{l}\text { SLEV and LCEV virus via } \\
\text { established CX. tarsalis/pipiens/ } \\
\text { restuans (SLEV) and Ae. } \\
\text { triseriatus (LCEV) populations } \\
\text { [73] }\end{array}$ & $\begin{array}{l}\text { CHIKV via the emergence of Ae. } \\
\text { albopictus in Canada (20) or malaria } \\
\text { via established An. freeborni and An. } \\
\text { quadrimaculatus populations (19) }\end{array}$ & $\begin{array}{l}\text { JE, Rift Valley fever and other exotic } \\
\text { MBDs where a natural competent vector } \\
\text { is not present in Canada (Table 1) }\end{array}$ \\
\hline \multirow[b]{2}{*}{$\begin{array}{l}\text { Anticipated disease } \\
\text { emergence in Canada with } \\
\text { climate change }\end{array}$} & \multirow[b]{2}{*}{$\begin{array}{l}\text { Locally-acquired cases } \\
\text { High possibility of becoming } \\
\text { endemic over time }\end{array}$} & Increase in travel-acquired cases & \multirow[b]{2}{*}{$\begin{array}{l}\text { Increase in travel-acquired cases, } \\
\text { but no further local mosquito-borne } \\
\text { transmission }\end{array}$} \\
\hline & & $\begin{array}{l}\text { Autochthonous cases or short-lived } \\
\text { autochthonous outbreaks transmitted } \\
\text { by emerging or established vector } \\
\text { populations } \\
\text { Possibility of becoming endemic over } \\
\text { time }\end{array}$ & \\
\hline
\end{tabular}

Abbreviations: Ae., Aedes; An., Anopheles; CHIKV, chikungunya virus; Cx., Culex; JE, Japanese encephalitis; LCEV, La Crosse encephalitis virus; MBD, mosquito-borne disease; SLEV, Saint Louis encephalitis virus; US, United States

The relationship between climate and MBDs is not linear. For example, temperatures above a certain threshold may reduce mosquito survival or slow pathogen replication in mosquitoes $(77,78)$. Thus, climate change can have an opposing effect on disease transmission such as supporting reservoir hosts while reducing pathogen and mosquito survival. There are other factors that will have a profound impact on exotic MBD emergence, including demographic changes (immigration and population growth) (79-82), increased mobility and interconnectivity $(79-81,83)$, urbanization and land use $(79,80,82)$, and socioeconomic factors (79-82,84,85); and some of these factors will also be influenced by climate change.
While the short-term risk of exotic MBD incursion and establishment in Canada, facilitated or exacerbated by climate change, is very low (49), it is feasible. The establishment of a new MBD has already been seen historically with West Nile virus $(6,67,69,86,87)$. Malaria is of particular concern given that it was once endemic in Canada (88), a suspected autochthonous case was reported in 1996 (89) and two dominant vectors are widespread in Canada (19). Exotic MBDs transmitted by Ae. albopictus are also of concern, with the recent incursion of this species into temperate regions elsewhere that are climatically similar to parts of Canada $(61,64,65,90)$ and the emergence of one small region in Canada where Ae. albopictus appears to have become established (20). Range expansion of this species within Canada will need to be monitored closely. 


\section{Conclusion}

The exact impact of climate change on exotic MBD emergence in Canada is difficult to quantify but there are expected to be more travel-acquired cases, a higher potential for short-lived autochthonous outbreaks of exotic MBDs and a higher risk for exotic MBDs to become endemic, particularly if the vectors are already present in Canada. Overall, there is a risk of establishment of exotic mosquitoes and MBDs in Canada with climate change, especially those transmitted by Aedes albopictus mosquitoes. Some of these impacts can be mitigated by adopting clinical and public health measures, including promoting awareness and use of mosquito bite prevention strategies, early detection and prompt response, ongoing active surveillance and mosquito control. Canadians need to be aware of the exotic MBDs that they are at risk for while travelling abroad as disease risk will only increase with climate change. Further, Canadians returning home serve as a potential route of introduction for exotic MBDs, making the need for awareness even more urgent.

\section{Authors' statement}

VN - Conceptualization, investigation, writing of original draft, supervision and project administration

EER - Writing: review and editing

LRL - Writing: review and editing

MAD - Writing: review and editing

TB - Investigation, writing: review and editing

TS — Investigation, writing: review and editing

SUK — Investigation, writing: review and editing

\section{Conflict of interest}

None.

\section{Funding}

This work was supported by the Public Health Agency of Canada.

\section{EXOTIC MOSQUITO-BORNE DISEASES*}

WHAT DISEASES

CURRENTLY SPORADIC CASES AFTER PEOPLE COME BACK FROM TRAVEL:

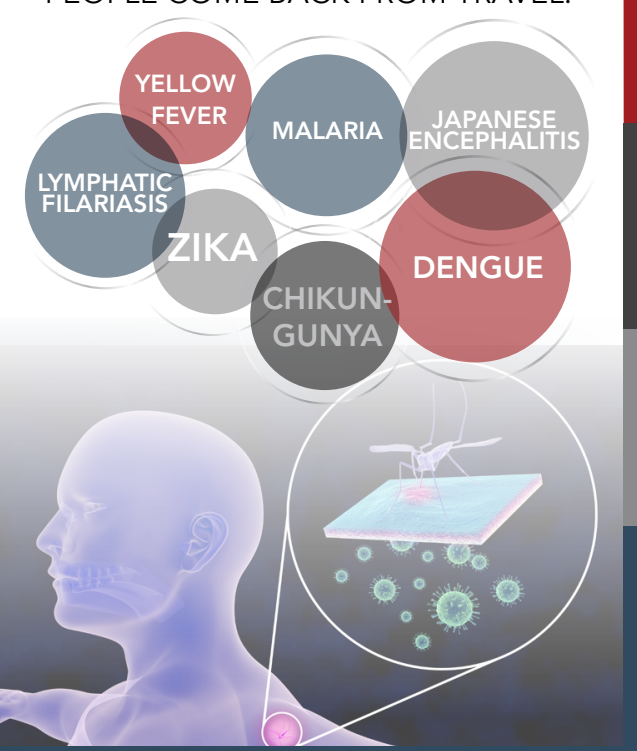

Citation: Ng V, Rees EE, Lindsay LR, Drebot

Can Commun Dis Rep 2019;45(4):98-107.

* Note: The association between exotic mosquito-borne diseases and climate change is non-linear and is influenced by other contexual factors
WHICH MOSOUITOES

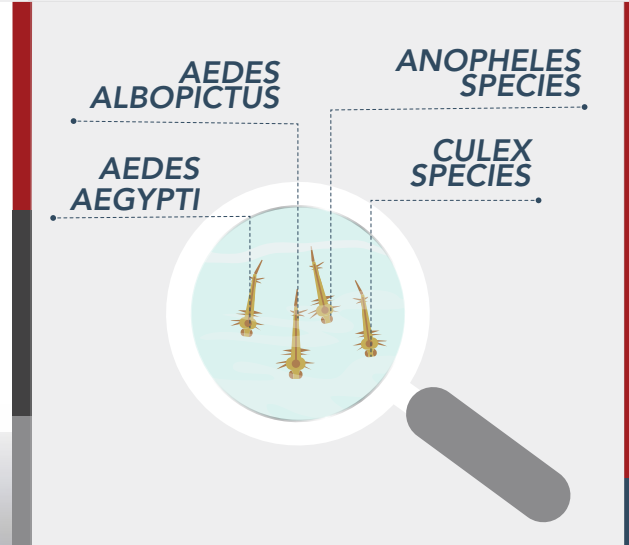

COULD BECOME ESTABLISHED IF:

- BROUGHT INTO CANADA

- THERE IS A CONDUCIVE ECOSYSTEM
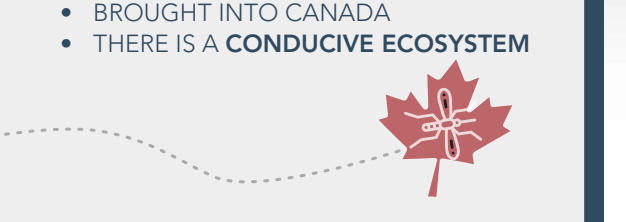

WHAT CLIMATE CHANGES

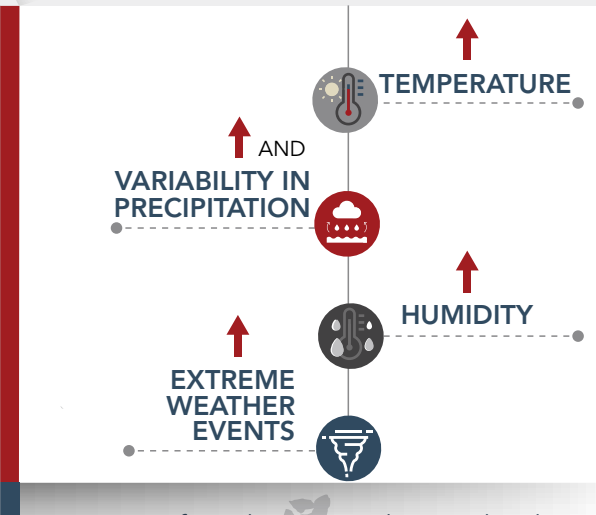

Areas of southern Canada may develop CONDUCIVE ECOSYSTEMS for EXOTIC MOSOUITO SPECIES

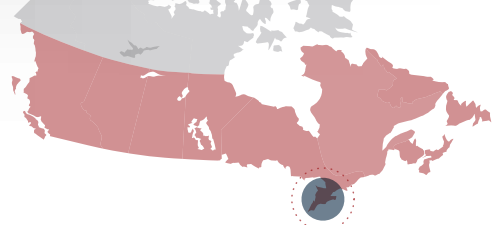

\section{.}

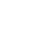




\section{References}

1. World Health Organization. Global vector control response 2017-2030. Geneva: World Health Organization; 2017. Licence: CC BY-NC-SA 3.0 IGO. 2017. p. 64.

2. Kraemer MU, Sinka ME, Duda KA, Mylne A, Shearer FM, Brady OJ, Messina JP, Barker CM, Moore CG, Carvalho RG, Coelho GE, Van Bortel W, Hendrickx G, Schaffner F, Wint GR, Elyazar IR, Teng HJ, Hay SI. The global compendium of Aedes aegypti and Ae. albopictus occurrence. Sci Data 2015 Jul;2:150035. DOI PubMed

3. Kamal M, Kenawy MA, Rady MH, Khaled AS, Samy AM. Mapping the global potential distributions of two arboviral vectors Aedes aegypti and Ae. albopictus under changing climate. PLoS One 2018 Dec;13(12):e0210122. DOI PubMed

4. Sinka ME, Bangs MJ, Manguin S, Rubio-Palis $Y$, Chareonviriyaphap T, Coetzee M, Mbogo CM, Hemingway J, Patil AP, Temperley WH, Gething PW, Kabaria CW, Burkot TR, Harbach RE, Hay SI. A global map of dominant malaria vectors. Parasit Vectors 2012 Apr;5(1):69. DOl PubMed

5. Madder DJ, Surgeoner GA, Helson BV. Induction of diapause in Culex pipiens and Culex restuans (Diptera: Culicidae) in southern Ontario. Can Entomol 1983;115(8):877-83. DOI

6. Giordano BV, Kaur S, Hunter FF. West Nile virus in Ontario, Canada: A twelve-year analysis of human case prevalence, mosquito surveillance, and climate data. PLoS One 2017 Aug;12(8):e0183568. DOl PubMed

7. Tataryn J, Vrbova L, Drebot M, Wood H, Payne E, Connors S, Geduld J, German M, Khan K, Buck PA. Travel-related Zika virus cases in Canada: October 2015-June 2017. Can Commun Dis Rep 2018 Jan;44(1):18-26. DOI PubMed

8. Boggild AK, Geduld J, Libman M, Yansouni CP, McCarthy $A E$, Hajek J, Ghesquiere W, Mirzanejad Y, Vincelette J, Kuhn S, Plourde PJ, Chakrabarti S, Freedman DO, Kain KC. Surveillance report of Zika virus among Canadian travellers returning from the Americas. CMAJ 2017 Mar;189(9):E334-40.DOI PubMed

9. Boggild AK, Geduld J, Libman M, Yansouni CP, McCarthy AE, Hajek J, Ghesquiere W, Vincelette J, Kuhn S, Freedman $\mathrm{DO}$, Kain KC. Malaria in travellers returning or migrating to Canada: surveillance report from CanTravNet surveillance data, 2004-2014. CMAJ Open 2016 Jul 6;4(3):E352-8. DOI PubMed

10. Drebot MA, Holloway K, Zheng H, Ogden NH. Travel-related chikungunya cases in Canada, 2014. Can Commun Dis Rep 2015 Jan;41(1):2-5. DOl PubMed

11. World Health Organization. Using climate to predict infectious disease epidemics. 2005, World Health Organisation: Geneva. p. 54.

12. Edited by David L. Heymann. Control of Communicable Diseases Manual, 20th Edition. 20th ed. 2014: APHA Press. 729.

13. European Centre for Disease Control. Aedes albopictus - Factsheet for experts: Epidemiology and transmission of pathogens. 2016. https://ecdc.europa.eu/en/diseasevectors/facts/mosquito-factsheets/aedes-albopictus

14. Leta S, Beyene TJ, De Clercq EM, Amenu K, Kraemer $\mathrm{MU}$, Revie CW. Global risk mapping for major diseases transmitted by Aedes aegypti and Aedes albopictus. Int J Infect Dis 2018 Feb;67:25-35. DOI PubMed

15. Ponlawat A, Harrington LC. Blood feeding patterns of Aedes aegypti and Aedes albopictus in Thailand. J Med Entomol 2005 Sep;42(5):844-9.DOI PubMed

16. Kiszewski A, Mellinger A, Spielman A, Malaney P, Sachs SE, Sachs J. A global index representing the stability of malaria transmission. Am J Trop Med Hyg 2004 May;70(5):486-98. DOl PubMed

17. World Health Organization. World Malaria Report 2018. 2018, World Health Organization: Geneva.

18. Cano J, Rebollo MP, Golding N, Pullan RL, Crellen T, Soler A, Kelly-Hope LA, Lindsay SW, Hay SI, Bockarie MJ, Brooker SJ. The global distribution and transmission limits of lymphatic filariasis: past and present. Parasit Vectors 2014 Oct; 7(1):466. DOI PubMed

19. Berrang-Ford L, Maclean JD, Gyorkos TW, Ford JD, Ogden $\mathrm{NH}$. Climate change and malaria in Canada: a systems approach. Interdiscip Perspect Infect Dis 2009;2009:385487. DOl PubMed

20. Windsor-Essex County Health Unit. Windsor-Essex County Health Unit - Aedes albopictus mosquito: 2018 adult mosquito survillance - Ae. albopictus mosquitoes identified. 2018. https://www.wechu.org/z-health-topics/aedesalbopictus-mosquito

21. Prakash G, Raju A, Koroivueta J. DF/DHF and Its Control in Fiji. 2001, World Health Organization. p. 21-27.

22. Dutton TJ, Sinkins SP. Filarial susceptibility and effects of Wolbachia in Aedes pseudoscutellaris mosquitoes. Med Vet Entomol 2005 Mar;19(1):60-5. DOI PubMed

23. Centres for Disease Control and Prevention. Vectors of Lymphatic Filariasis. 2018. https://www.cdc.gov/parasites/ lymphaticfilariasis/gen_info/vectors.html

24. Longbottom J, Browne AJ, Pigott DM, Sinka ME, Golding N, Hay SI, Moyes CL, Shearer FM. Mapping the spatial distribution of the Japanese encephalitis vector, Culex tritaeniorhynchus Giles, 1901 (Diptera: Culicidae) within areas of Japanese encephalitis risk. Parasit Vectors 2017 Mar;10(1):148. DOI PubMed

25. Miller RH, Masuoka P, Klein TA, Kim HC, Somer T, Grieco $J$. Ecological niche modeling to estimate the distribution of Japanese encephalitis virus in Asia. PLoS Negl Trop Dis 2012;6(6):e1678. DOI PubMed

26. Statistics Canada. Table 24-10-0041-01 International travellers entering or returning to Canada, by type of transport. 2019. https://www150.statcan.gc.ca/t1/tb/1/en/ tv. action?pid=2410004101 
27. Statistics Canada. Table 24-10-0037-01 Travel by Canadians to foreign countries, top 15 countries visited. 2019. https:// www150.statcan.gc.ca/t1/tb/1/en/cv.action?pid=2410003701

28. Boggild AK, Geduld J, Libman M, Ward BJ, McCarthy A, Hajek J, Ghesquiere W, Vincelette J, Kuhn S, Freedman DO, Kain KC. Travel-acquired infections in Canada: CanTravNet 2011-2012. Can Commun Dis Rep 2014 Sep;40(16):313-25. DOI PubMed

29. Boggild AK, Geduld J, Libman M, Ward BJ, McCarthy AE, Doyle PW, Ghesquiere W, Vincelette J, Kuhn S, Freedman DO, Kain KC. Travel-acquired infections and illnesses in Canadians: surveillance report from CanTravNet surveillance data, 2009-2011. Open Med 2014 Feb;8(1):e20-32. PubMed

30. Government of Canada. Reported cases from 1924 to 2016 in Canada - Notifiable diseases on-line. 2019. http:// diseases.canada.ca/notifiable/charts?c=pl

31. World Health Organization. Dengue Control. 2019. https:// www.who.int/denguecontrol/disease/en/

32. Ebi $\mathrm{KL}$, Nealon J. Dengue in a changing climate. Environ Res 2016 Nov;151:115-23. DOI PubMed

33. Pan American Health Organization. Chikungunya: Data, Maps and Statistics. 2017. https://www.paho.org/hq/index. php?option=com_topics\&view=rdmore\&cid=5927\&item $=$ chi kungunya\&type $=$ statistics\&ltemid $=40931 \& \mid$ ang $=$ en

34. Pan American Health Organization. Zika cases and congenital syndrome associated with Zika virus reported by countries and territories in the Americas, 2015-2018. Cumulative cases. 2018. https://www.paho.org/hq/index.php?option=com docman\&view=download\&category_slug=cumulative-casespdf-8865\&alias=43296-zika-cumulative-cases-4-january2018-296\&ltemid=270\&lang=en

35. Ogden NH, Fazil A, Safronetz D, Drebot MA, Wallace J Rees EE, Decock K, Ng V. Risk of travel-related cases of Zika virus infection is predicted by transmission intensity in outbreak-affected countries. Parasit Vectors 2017 Jan;10(1):41. DOl PubMed

36. Faria NR, Kraemer MU, Hill SC, Goes de Jesus J, Aguiar RS, Iani FC, Xavier J, Quick J, du Plessis L, Dellicour S, Thézé J, Carvalho RD, Baele G, Wu CH, Silveira PP, Arruda MB, Pereira MA, Pereira GC, Lourenço J, Obolski U, Abade L, Vasylyeva TI, Giovanetti M, Yi D, Weiss DJ, Wint GR, Shearer FM, Funk S, Nikolay B, Fonseca V, Adelino TE, Oliveira MA, Silva MV, Sacchetto L, Figueiredo PO, Rezende IM, Mello EM, Said RF, Santos DA, Ferraz ML, Brito MG, Santana LF, Menezes MT, Brindeiro RM, Tanuri A, Dos Santos FC, Cunha MS, Nogueira JS, Rocco IM, da Costa AC, Komninakis SC, Azevedo V, Chieppe AO, Araujo ES, Mendonça MC, Dos Santos CC, Dos Santos CD, Mares-Guia AM, Nogueira RM, Sequeira PC, Abreu RG, Garcia MH, Abreu AL, Okumoto O, Kroon EG, de Albuquerque CF, Lewandowski K, Pullan ST, Carroll M, de Oliveira T, Sabino EC, Souza RP, Suchard MA, Lemey $P$, Trindade GS, Drumond BP, Filippis AM, Loman NJ, Cauchemez S, Alcantara LC, Pybus OG. Genomic and epidemiological monitoring of yellow fever virus transmission potential. Science 2018 Aug;361(6405):894-9. DOI PubMed

37. Possas C, Lourenço-de-Oliveira R, Tauil PL, Pinheiro FP, Pissinatti A, Cunha RV, Freire M, Martins RM, Homma A.
Yellow fever outbreak in Brazil: the puzzle of rapid viral spread and challenges for immunisation. Mem Inst Oswaldo Cruz 2018 Sep;113(10):e180278. DOI PubMed

38. Kwagonza L, Masiira B, Kyobe-Bosa H, Kadobera D, Atuheire EB, Lubwama B, Kagirita A, Katushabe E, Kayiwa JT, Lutwama JJ, Ojwang JC, Makumbi I, Ario AR, Borchert J, Zhu BP. Outbreak of yellow fever in central and southwestern Uganda, February-may 2016. BMC Infect Dis 2018 Nov;18(1):548. DOl PubMed

39. Ahuka-Mundeke S, Casey RM, Harris JB, Dixon MG, Nsele PM, Kizito GM, Umutesi G, Laven J, Paluku G, Gueye AS, Hyde TB, Sheria GK, Muyembe-Tanfum JJ, Staples JE. Immunogenicity of Fractional-Dose Vaccine during a Yellow Fever Outbreak - Preliminary Report. N Engl J Med 2018 Feb. DOI PubMed

40. Gotuzzo E, Yactayo S, Córdova E. Efficacy and duration of immunity after yellow fever vaccination: systematic review on the need for a booster every 10 years. Am J Trop Med Hyg 2013 Sep;89(3):434-44. DOI PubMed

41. Romero-Lankao P, Smith J, Davidson D, Diffenbaugh N, Kinney P, Kirshen P, Kovacs P, Villers Ruiz L. North America. In: Climate Change 2014: Impacts, Adaptation, and Vulnerability. Part B: Regional Aspects. Contribution of Working Group II to the Fifth Assessment Report of the Intergovernmental Panel on Climate Change [Barros, V.R., C.B. Field, D.J. Dokken, M.D. Mastrandrea, K.J. Mach, T.E. Bilir, M. Chatterjee, K.L. Ebi, Y.O. Estrada, R.C. Genova, B. Girma, E.S. Kissel, A.N. Levy, S. MacCracken, P.R. Mastrandrea, and L.L. White (eds.)]. 2014: Cambridge University Press, Cambridge, United Kingdom and New York, NY, USA. p. 1439-1498.

42. Jetten TH, Focks DA. Potential changes in the distribution of dengue transmission under climate warming. Am J Trop Med Hyg 1997 Sep;57(3):285-97. DOI PubMed

43. Reeves WC, Hardy JL, Reisen WK, Milby MM. Potential effect of global warming on mosquito-borne arboviruses. J Med Entomol 1994 May;31(3):323-32. DOl PubMed

44. Yang HM, Macoris ML, Galvani KC, Andrighetti MT, Wanderley DM. Assessing the effects of temperature on the population of Aedes aegypti, the vector of dengue. Epidemiol Infect 2009 Aug;137(8):1188-202. DOI PubMed

45. Paaijmans KP, Read AF, Thomas MB. Understanding the link between malaria risk and climate. Proc Natl Acad Sci USA 2009 Aug;106(33):13844-9. DOI PubMed

46. Paaijmans KP, Cator LJ, Thomas MB. Temperature-dependent pre-bloodmeal period and temperature-driven asynchrony between parasite development and mosquito biting rate reduce malaria transmission intensity. PLoS One 2013;8(1):e55777. DOl PubMed

47. Davis NC. The effect of various temperatures in modifying the extrinsic incubation period of the yellow fever virus in Aedes aegypti*. Am J Epidemiol 1932;16(1):163-76. DOI

48. Xiao FZ, Zhang Y, Deng YQ, He S, Xie HG, Zhou XN, Yan YS. The effect of temperature on the extrinsic incubation period and infection rate of dengue virus serotype 2 infection in Aedes albopictus. Arch Virol 2014 Nov;159(11):3053-7. DOI PubMed 
49. Ng V, Fazil A, Gachon P, Deuymes G, Radojević M, Mascarenhas M, Garasia S, Johansson MA, Ogden NH. Assessment of the Probability of Autochthonous Transmission of Chikungunya Virus in Canada under Recent and Projected Climate Change. Environ Health Perspect 2017 Jun;125(6):067001. DOI PubMed

50. Ogden NH, Milka R, Caminade C, Gachon P. Recent and projected future climatic suitability of North America for the Asian tiger mosquito Aedes albopictus. Parasit Vectors 2014 Dec;7:532. DOl PubMed

51. Clement J, Vercauteren J, Verstraeten WW, Ducoffre G, Barrios JM, Vandamme AM, Maes P, Van Ranst M. Relating increasing hantavirus incidences to the changing climate: the mast connection. Int J Health Geogr 2009 Jan;8:1.DOI PubMed

52. Ng V, Dear K, Harley D, McMichael A. Analysis and prediction of Ross River virus transmission in New South Wales, Australia. Vector Borne Zoonotic Dis 2014 Jun;14(6):422-38. DOl PubMed

53. Harrigan RJ, Thomassen HA, Buermann W, Smith TB. A continental risk assessment of West Nile virus under climate change. Glob Change Biol 2014 Aug;20(8):2417-25. DOI PubMed

54. Shaman J, Day JF, Stieglitz M. Drought-induced amplification and epidemic transmission of West Nile virus in southern Florida. J Med Entomol 2005 Mar;42(2):134-41. DOI PubMed

55. Wang G, Minnis RB, Belant JL, Wax CL. Dry weather induces outbreaks of human West Nile virus infections. BMC Infect Dis 2010 Feb;10:38. DOI PubMed

56. Giladi M, Metzkor-Cotter E, Martin DA, Siegman-lgra Y, Korczyn AD, Rosso R, Berger SA, Campbell GL, Lanciotti RS. West Nile encephalitis in Israel, 1999: the New York connection. Emerg Infect Dis 2001 Jul-Aug;7(4):659-61. DOI PubMed

57. Lanciotti RS, Roehrig JT, Deubel V, Smith J, Parker M, Steele K, Crise B, Volpe KE, Crabtree MB, Scherret JH, Hall RA, MacKenzie JS, Cropp CB, Panigrahy B, Ostlund E, Schmitt B, Malkinson M, Banet C, Weissman J, Komar N, Savage HM, Stone W, McNamara T, Gubler DJ. Origin of the West Nile virus responsible for an outbreak of encephalitis in the northeastern United States. Science 1999 Dec;286(5448):2333-7. DOI PubMed

58. Giordano BV, Gasparotto A, Hunter FF. A checklist of the 67 mosquito species of Ontario, Canada. J Am Mosq Control Assoc 2015 Mar;31(1):101-3. DOI PubMed

59. Centres for Disease Control and Prevention. Saint Louis encephalitis: Epidemiology and Geographic Distribution. 2018 November 2, 2018]; https://www.cdc.gov/sle/technical/ epi.html

60. Centres for Disease Control and Prevention. La Crosse encephalitis: Epidemiology and Geographic Distribution. 2018. https://www.cdc.gov/lac/tech/epi.html

61. Venturi G, Di Luca M, Fortuna C, Remoli ME, Riccardo F, Severini F, Toma L, Del Manso M, Benedetti E, Caporali MG, Amendola A, Fiorentini C, De Liberato C, Giammattei R, Romi R, Pezzotti P, Rezza G, Rizzo C. Detection of a chikungunya outbreak in Central Italy, August to September 2017. Euro Surveill 2017 Sep;22(39):17-00646. DOl PubMed

62. Septfons A, Leparc-Goffart I, Couturier E, Franke F, Deniau J, Balestier A, Guinard A, Heuzé G, Liebert AH, Mailles A, Ndong JR, Poujol I, Raguet S, Rousseau C, Saidouni-Oulebsir A, Six C, Subiros M, Servas V, Terrien E, Tillaut H, Viriot D, Watrin M, Wyndels K, Noel H, Paty MC, De Valk H; Zika Surveillance Working Group in French departments and collectivities of the Americas. Travel-associated and autochthonous Zika virus infection in mainland France, 1 January to 15 July 2016. Euro Surveill 2016 Aug;21(32). DOI PubMed

63. Likos A, Griffin I, Bingham AM, Stanek D, Fischer M, White S, Hamilton J, Eisenstein L, Atrubin D, Mulay P, Scott B, Jenkins P, Fernandez D, Rico E, Gillis L, Jean R, Cone M, Blackmore C, McAllister J, Vasquez C, Rivera L, Philip C. Local Mosquito-Borne Transmission of Zika Virus - Miami-Dade and Broward Counties, Florida, June-August 2016. MMWR Morb Mortal Wkly Rep 2016 Sep;65(38):1032-8. DOI PubMed

64. Rezza G, Nicoletti L, Angelini R, Romi R, Finarelli AC, Panning M, Cordioli P, Fortuna C, Boros S, Magurano F, Silvi G, Angelini P, Dottori M, Ciufolini MG, Majori GC, Cassone $A ; C H I K V$ study group. Infection with chikungunya virus in Italy: an outbreak in a temperate region. Lancet 2007 Dec;370(9602):1840-6. DOI PubMed

65. Delisle E, Rousseau C, Broche B, Leparc-Goffart I, L'Ambert G, Cochet A, Prat C, Foulongne V, Ferre JB, Catelinois $O$, Flusin $O$, Tchernonog E, Moussion IE, Wiegandt A, Septfons A, Mendy A, Moyano MB, Laporte L, Maurel J, Jourdain F, Reynes J, Paty MC, Golliot F. Chikungunya outbreak in Montpellier, France, September to October 2014. Euro Surveill 2015 Apr;20(17):21108. DOI PubMed

66. Bouri N, Sell TK, Franco C, Adalja AA, Henderson DA, Hynes NA. Return of epidemic dengue in the United States: implications for the public health practitioner. Public Health Rep 2012 May-Jun;127(3):259-66. DOl PubMed

67. Artsob H, Gubler DJ, Enria DA, Morales MA, Pupo M, Bunning ML, Dudley JP. West Nile Virus in the New World: trends in the spread and proliferation of West Nile Virus in the Western Hemisphere. Zoonoses Public Health 2009 Aug;56(6-7):357-69. DOI PubMed

68. Gubler DJ. The continuing spread of West Nile virus in the western hemisphere. Clin Infect Dis 2007 Oct;45(8):1039-46. DOI PubMed

69. Zheng H, Drebot MA, Coulthart MB. West Nile virus in Canada: ever-changing, but here to stay. Can Commun Dis Rep 2014 May;40(10):173-7.DOI PubMed

70. McMichael C, Barnett J, McMichael AJ. An ill wind? Climate change, migration, and health. Environ Health Perspect 2012 May; 120(5):646-54. DOl PubMed

71. World Tourism Organization and United Nations Environment Programme. Climate Change and Tourism - Responding to Global Challenges. 2008, World Tourism Organization: Madrid, Spain. p. 269. 
72. Findlater A, Bogoch II. Human Mobility and the Global Spread of Infectious Diseases: A Focus on Air Travel. Trends Parasitol 2018 Sep;34(9):772-83. DOI PubMed

73. Giordano BV, Turner KW, Hunter FF. Geospatial Analysis and Seasonal Distribution of West Nile Virus Vectors (Diptera: Culicidae) in Southern Ontario, Canada. Int J Environ Res Public Health 2018 Mar;15(4):E614. DOI PubMed

74. Ogden NH. Climate change and vector-borne diseases of public health significance. FEMS Microbiol Lett 2017 Oct;364(19). DOI PubMed

75. Rochlin I, Ninivaggi DV, Hutchinson ML, Farajollahi A. Climate change and range expansion of the Asian tiger mosquito (Aedes albopictus) in Northeastern USA: implications for public health practitioners. PLoS One 2013;8(4):e60874.DOI PubMed

76. Fischer D, Thomas SM, Suk JE, Sudre B, Hess A, Tjaden NB, Beierkuhnlein C, Semenza JC. Climate change effects on Chikungunya transmission in Europe: geospatial analysis of vector's climatic suitability and virus' temperature requirements. Int J Health Geogr 2013 Nov;12:51. DOI PubMed

77. Reisen WK. Effect of temperature on Culex tarsalis (Diptera: Culicidae) from the Coachella and San Joaquin Valleys of California. J Med Entomol 1995 Sep;32(5):636-45. DOI PubMed

78. Reisen WK, Fang Y, Martinez VM. Effects of temperature on the transmission of west nile virus by Culex tarsalis (Diptera: culicidae). J Med Entomol 2006 Mar;43(2):309-17. DOI PubMed

79. Kilpatrick AM, Randolph SE. Drivers, dynamics, and control of emerging vector-borne zoonotic diseases. Lancet 2012 Dec;380(9857):1946-55. DOl PubMed

80. Romeo-Aznar V, Paul R, Telle O, Pascual M. Mosquito-borne transmission in urban landscapes: the missing link between vector abundance and human density. Proc Biol Sci 2018 Aug;285(1884). DOI PubMed
81. Lindsey NP, Staples JE, Fischer M. Chikungunya Virus Disease among Travelers-United States, 2014-2016. Am J Trop Med Hyg 2018 Jan;98(1):192-7. DOI PubMed

82. Jones B, O’Neill B. Spatially explicit global population scenarios consistent with the Shared Socioeconomic Pathways. Environ Res Lett 2016;11(084003). DOI

83. Tatem AJ, Hay SI, Rogers DJ. Global traffic and disease vector dispersal. Proc Natl Acad Sci USA 2006 Apr;103(16):6242-7. DOI PubMed

84. Kc S, Lutz W. The human core of the shared socioeconomic pathways: population scenarios by age, sex and level of education for all countries to 2100. Glob Environ Change 2017 Jan;42:181-92. DOl PubMed

85. Moreno-Madriñán MJ, Turell M. History of Mosquitoborne Diseases in the United States and Implications for New Pathogens. Emerg Infect Dis 2018 May;24(5):821-6. DOI PubMed

86. Paz S. Climate change impacts on West Nile virus transmission in a global context. Philos Trans R Soc Lond B Biol Sci 2015 Apr;370(1665):20130561. DOI PubMed

87. Reisen WK. Ecology of West Nile virus in North America. Viruses 2013 Sep;5(9):2079-105. DOI PubMed

88. Fallis AM. Malaria in the 18th and 19th centuries in Ontario. Bull Can Hist Med 1984;1(2):25-38. DOl PubMed

89. Baqi M, Gamble K, Keystone JS, Kain KC. Malaria: Probably locally acquired in Toronto, Ontario. Can J Infect Dis 1998 May;9(3):183-4. DOl PubMed

90. Calba C, Guerbois-Galla M, Franke F, Jeannin C, Auzet-Caillaud M, Grard G, Pigaglio L, Decoppet A, Weicherding J, Savaill MC, Munoz-Riviero M, Chaud P, Cadiou B, Ramalli L, Fournier P, Noël H, De Lamballerie $X$, Paty MC, Leparc-Goffart I. Preliminary report of an autochthonous chikungunya outbreak in France, July to September 2017. Euro Surveill 2017 Sep;22(39). DOI PubMed 